\title{
Marc Dambre, Roger Nimier et l'Algérie (1953-1962)
}

\section{Chiara Rolla}

\section{(2) OpenEdition}

\section{Journals}

\section{Edizione digitale}

URL: https://journals.openedition.org/studifrancesi/41271

DOI: 10.4000/studifrancesi.41271

ISSN: 2421-5856

\section{Editore}

Rosenberg \& Sellier

\section{Edizione cartacea}

Data di pubblicazione: 1 juillet 2004

Paginazione: 224

ISSN: 0039-2944

\section{Notizia bibliografica digitale}

Chiara Rolla, «Marc Dambre, Roger Nimier et l'Algérie (1953-1962)», Studi Francesi [Online], 142 (XLVIII I

I) | 2004, online dal 30 novembre 2015, consultato il 09 septembre 2021. URL: http://

journals.openedition.org/studifrancesi/41271 ; DOI: https://doi.org/10.4000/studifrancesi.41271

\section{Questo documento è stato generato automaticamente il 9 septembre 2021.}

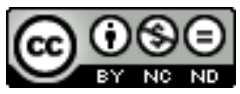

Studi Francesi è distribuita con Licenza Creative Commons Attribuzione - Non commerciale - Non opere derivate 4.0 Internazionale. 


\title{
Marc Dambre, Roger Nimier et l'Algérie (1953-1962)
}

\author{
Chiara Rolla
}

\section{NOTIZIA}

MARC DAMBRE, Roger Nimier et l'Algérie (1953-1962), in La plume dans la plaie. Les écrivains

journalistes et la guerre d'Algérie, Ph. Baudorre éd., P. U. de Bordeaux, 2003, pp.149-167.

1 Molto rari sono i testi che nei nove anni del suo silenzio narrativo Nimier dedica all'Africa del Nord. Un solo articolo ha infatti per oggetto l'Algeria e la guerra che là si stava svolgendo e di cui lo scrittore fu diretto testimone durante il suo soggiorno algerino del 1953.

2 Il carteggio con Jacques Chardonne rivela «une atmosphère de légèreté» (p.151) e un atteggiamento demistificatorio verso i luoghi sede della Legione Straniera, pur essendo stato comunque Nimier profondamente affascinato dai legionari, "guerriers qui conjuguent aventure, professionnalisme et cosmopolitisme» (p.153). Dai testi che Dambre prende in esame non traspare alcuna presa di posizione in favore dell'Algeria francese, bensì una decisa critica contro quegli intellettuali che attraverso «un mensonge politique» (p.156) sfruttavano quella guerra per pura propaganda politica. Nimier, vero e proprio «contre-intellectuel» (p.163) non partecipò dunque, secondo Dambre, alla battaglia intellettuale che animò gli anni della guerra d'Algeria, ma ne restò a margine, testimoniando invece una sincera solidarietà interiore verso le tragedie umane che quel conflitto, come ogni altro, ha implicato. 